\title{
Śmierć jako nośnik znaczeń symbolicznych - w poszukiwaniu patrystycznych inspiracji Pseudo-Garniera z Langres
}

W połowie XII wieku powstał w cysterskim opactwie w Clairvaux glosariusz symbolicznych znaczeń poszczególnych motywów biblijnych w oparciu o interpretacje Ojców Kościoła i wcześniejszych pisarzy średniowiecznych. Dzieło, pierwotnie noszące tytuł Angelus, następnie zaś Allegoriae totius sacrae Scripturae, zostało rozpowszechnione przez opata Garniera z Langres, następcę św. Bernarda z Clairvaux na tym urzędzie, a następnie biskupa Rochefort, stąd też jemu jest przypisywane ${ }^{2}$.

W ramach prac nad wydaniem krytycznym dzieła ${ }^{3}$ podjąłem się również kwerendy mającej na celu dotarcie do niektórych źródeł interpretacji zawartych w glosariuszu. Jego autor czasami sięga do konkretnych ko-

1 Ks. prof. dr hab. Krzysztof Bardski, profesor w Instytucie Nauk Teologicznych na Wydziale Teologicznym Uniwersytetu Kardynała Stefana Wyszyńskiego w Warszawie, kierownik Katedry Teologii i Hermeneutyki Biblijnej; e-mail: kbardski@yahoo.com; ORCID: 0000-0002-8340-3993.

2 Szerzej na temat samego dzieła jego i charakterystyki, zob. K. Bardski, Medieval Glossary of Biblical Symbols - Pseudo-Garnier's of Langres „Allegoriae in Universam Sacram Scripturam”, ,Wrocławski Przegląd Teologiczny” 27/2 (2019) s. 33-42. Na temat atrybucji, zob. A. Wilmart, Les Allégories sur l'Écriture attribuées à Raban Maur, „Revue Bénedictine" 32 (1920) s. 47-56; F. Stegmüller, Repertorium Biblicum Medii Aevi, t. 2, Madrid 1950, s. 2364; P. Glorieux, Pour revaloriser Migne, Mélanges de science religieuse. Cahier supplémentaire, Lille 1952, s. 56.

3 Projekt wydania krytycznego powstaje w ramach grantu 22H 17034485 Narodowego Programu Rozwoju Humanistyki. Dotychczasowe wydanie, opublikowane wśród dzieł Rabana Maura (PL 112, 849-1088), jest niepełne i wadliwe. W konsekwencji oparte na nim przekłady na język włoski (Rabano Mauro (pseudo), Allegorie sulla Scrittura, tł. P.G. di Domenico, Città del Vaticano 2002) oraz angielski (Anonymous, 
mentarzy patrystycznych lub średniowiecznych, czasami przytacza wyjaśnienie obecne w szeroko pojętej tradycji, innym zaś razem tworzy własną interpretację na bazie pierwiastków symbolotwórczych poszczególnych motywów biblijnych.

W niniejszym artykule zbadamy hermeneutyczne podejście do tekstu biblijnego oraz tradycji patrystycznej, które zaowocowało powstaniem glosariusza, oraz spróbujemy zastanowić się nad zjawiskiem interpretacji alegorycznej, w ramach której powstały zawarte w nim wyjaśnienia ${ }^{4}$.

Śmierć jest podstawowym archetypicznym doświadczeniem kresu. $\mathrm{Z}$ punktu widzenia podmiotu ma jednak zawsze charakter perspektywiczny, nigdy dokonany. Jako złożone doświadczenie egzystencjalne częściej była symbolizowana niż symbolizująca. Bogata ikonografia przedstawia ją pod postacią kościotrupa, klepsydry, kosy, zgaszonego płomyka, czarnego koloru, krzyża i wielu innych. Sama śmierć może też jednak symbolizować inne rzeczywistości. Tak też dzieje się w przypadku glosariusza Pseudo-Garniera z Langres. Śmierć jest jedną z nielicznych rzeczywistości, które są zarazem paralelą intencjonalną dla innych rzeczy symbolicznych ${ }^{5}$ (coś przywołuje na myśl śmierć), jak i nośnikiem dla pewnych treści symbolicznych (śmierć przywołuje na myśl coś). Z jednej strony śmierć stanowi paralelę intencjonalną dla takich symboli, jak wieloryb („,cetus”), dom (,domus”), zaśnięcie („dormitio”), sierp („falx”), koniec („finis”), miecz („framea” oraz ,gladius”), owoc („,fructus”), mirra (,myrrha”), ryba (,,piscis”), krew (,,sanguis”) i sen (,somnus”). Z drugiej zaś słownik symboliki biblijnej Pseudo-Garniera z Langres zawiera sześć interpretacji symbolicznych śmierci: umartwienie („mortificatio”), pycha (,superbia”), diabeł („,diabolus”), nienawiść do braci („fraternum odium”), grzech (,peccatum”) i kara wieczna (,poena aeterna”). W niniejszym artykule zajmiemy się tymi sześcioma ostatnimi interpretacjami śmierci jako „res simbolica”, pozostawiając wymienione wcześniej interpretacje śmierci jako paraleli intencjonalnej na tematykę odrębnego artykułu.

Allegories in All Holy Scripture, tł. P. Throop, Vermont 2009) ponoszą konsekwencje ułomności podstawy tłumaczenia.

4 Szerzej na temat interpretacji symboliczno-alegorycznej Biblii w starożytności i średniowieczu, zob. K. Bardski, Alegoryczno-symboliczna interpretacja Biblii, Kraków 2016.

5 Na temat pojęcia ,rzeczy symbolicznych”, zob. K. Bardski, Rzecz-symbol jako locus theologicus w ponaddostownej interpretacji Biblii, „Ethos” 33/3 (2020) 33-53. 


\section{1. Śmierć jako umartwienie („mortificatio”)}

Pierwsza interpretacja, jaką znajdujemy w glosariuszu PseudoGarniera z Langres, odwołuje się właściwie do literalnego znaczenia, jednak sugeruje znaczenie metaforyczne zawarte w łacińskim „mortificare” ('umartwić'):

Śmierć to jest ustanie życia doczesnego, jak w Księdze Hioba: „Którzy oczekują śmierci, a nie przychodzi” (Hi 3,21), gdyż święci pragną całkowitego umartwienia względem tego świata, lecz go nie osiągają („Mors est exstinctio vitae saecularis, ut in Job: Qui exspectant ${ }^{6}$ mortem, et non venit ${ }^{7}$, quia ${ }^{8}$ sancti funditus se ab hoc mundo mortificare volunt, sed non possunt") ${ }^{9}$.

Idea pragnienia śmierci zawarta w powyższej interpretacji wydaje się niezbyt szczęśliwym odczytaniem wersetu z Księgi Hioba, który w kontekście biblijnym odnosi się do ludzi zrozpaczonych i zgorzkniałych, podczas gdy pragnienie śmierci człowieka świętego, który tęskni za wiecznością, wzgardziwszy rozkoszami światowymi, ma wydźwięk pozytywny. Skąd autor zaczerpnął taką interpretację? Otóż zarówno pod względem sensu, jak i podobieństw leksykalnych jest ona streszczeniem interpretacji Grzegorza Wielkiego zawartej w Moraliach, w komentarzu do tego wersetu:

W istocie pragną całkowicie obumrzeć dla wszelkiej chwały doczesnego życia. Lecz często na mocy ukrytych wyroków Boga zmuszeni są do sprawowania władzy czy do przyjmowania związanych z tym zaszczytów. A jednak pośród tych zajęć nieustannie oczekują oni pełnego obumarcia. Oczekiwana śmierć jednak nie nadchodzi, ponieważ wciąż żyje w nich - nawet wbrew woli - przyzwyczajenie do doczesnej chwały, którą mimo wszystko znoszą przez wzgląd na bojaźń Bożąa ${ }^{10}$.

6 exspectant] exspectat $m$ (w ten sposób oznaczamy warianty tekstualne różniące wydanie Migne'a od przygotowywanego wydania krytycznego, którego fragmenty cytujemy w niniejszym artykule).

7 non venit] invenit $m$.

8 quia] quod $m$.

9 Pseudo-Garnerius Lingonensis, Allegoriae totius Sacrae Scripturae, Mors, PL 112, 1002A.

10 "Desiderant quippe mortificare se funditus, atque ab omni vita gloriae temporalis exstinguere; sed occultis saepe Dei iudiciis vel praeesse in regimine, vel occupari iniunctis honoribus compelluntur, atque inter haec mortificationem plenissimam indesinenter exspectant. Sed exspectata mors non venit, quia eorum usus temporali gloriae etiam no- 
Mimo pewnej nieadekwatności względem pierwotnego przesłania biblijnego interpretacja Grzegorza Wielkiego, która w istocie jest zaaplikowaniem sensu wersetu wyrwanego z kontekstu do wczesnośredniowiecznej ascetyki, ze względu na autorytet jej twórcy zyskała popularność. Poza Pseudo-Garnierem z Langres została również zacytowana w formie skróconej w kompilacji Glossa Ordinaria przypisywanej środowisku Alzelma $\mathrm{z}$ Laon ${ }^{11}$. Nietrudno dostrzec $\mathrm{w}$ niej echo osobistych doświadczeń autora, który jako pierwszy mnich benedyktyński został powołany na Stolicę Piotrową i sam mógł uznać siebie za zaliczonego do grona tych, co „na mocy ukrytych wyroków Boga zmuszeni są do sprawowania władzy czy do przyjmowania związanych z tym zaszczytów".

\section{2. Śmierć jako pycha (,superbia”)}

Według drugiej interpretacji Pseudo-Garniera z Langres śmierć symbolizuje pychę ludzką:

Śmierć to pycha, jak w Księdze Hioba: „Niech trawi ramiona jego śmierć pierworodna" (Hi 18,13), gdyż dobre czyny bezbożnego niszczy pycha, która była pierwszym grzechem („Mors, superbia, ut in Job: Consumat brachia illius primogenita mors, quia ${ }^{12}$ bona opera impii superbia, quae fuit primum peccatum, destruit $\left.{ }^{13 "}\right)^{14}$.

Tym razem kontekst biblijny zostaje uszanowany przez interpretatora. Negatywny wydźwięk wersetu nie koliduje z przesłaniem Księgi Hioba, cytat bowiem został zaczerpnięty z wypowiedzi mędrca Bildada z Szuach, który przedstawia udręki, jakie dotykają człowieka obłudnego (Hi 18,5). Symbolika śmierci zostaje tu połączona $\mathrm{z}$ archetypiczną symboliką ramion,

lens vivit, quam tamen pro divino timore tolerant" (Gregorius I, Moralia 5, 4, 5 ad Job 3,21, tł. T. Fabiszak - A. Strzelecka - R. Wójcik, Grzegorz Wielki, Moralia. Komentarz do Księgi Hioba, tom 1, ks.1-5, ŹM 39, Tyniec 2006, s. 376).

11 Anselmus Laudunensis, Radulfus Laudunensis et schola, Glossa Ordinaria, In Job, ad loc: "Qui exspectant mortem, id est, penitus se mundo mortificare desiderant, sed occulto Dei judicio non venit, quia occupari injunctis honoribus compelluntur, quod Dei timore tolerant".

12 quia] quod $m$

13 destruit] destruet $m$

14 Pseudo-Garnerius Lingonensis, Allegoriae totius Sacrae Scripturae, Mors, PL 112, 1002A. 
które oznaczają ludzkie czyny. Skąd jednak autor zaczerpnął pomysł skojarzenia pychy ze ,śmiercią pierworodną”? Również tutaj odpowiedź znajdziemy w Moraliach Grzegorza Wielkiego:

Mianem ramion zaś nie bez racji określone zostały uczynki, ponieważ uczynków ciała dokonuje się przy pomocy ramion. Czymże zaś jest śmierć, jeśli nie grzechem, który zabójczo odcina duszę od wewnętrznego życia? Dlatego napisano: „Błogosławiony i święty ten, kto ma udział w pierwszym zmartwychwstaniu" (Ap 20,6), gdyż ten w przyszłości szczęśliwie zmartwychwstanie w ciele, kto w tym życiu zmartwychwstanie ze śmierci swego umysłu. Jeśli zatem grzech jest śmiercią, nie bez racji jako śmierć pierworodną należy rozumieć pychę, gdyż jest napisane: „Początkiem wszelkiego grzechu jest pycha" (Syr 10,15). Zatem piękno jego skóry i ramiona jego trawi śmierć pierworodna, gdyż pycha leży u podłoża chwały i postępowania bezbożnika. Mógłby nawet przejść przez życie w chwale i bez winy, gdyby tylko nie był pyszny ${ }^{15}$.

Dopiero w świetle cytatu z Księgi Syracydesa przytoczonego przez Grzegorza Wielkiego odkrywamy sens określenia pychy mianem ,pierwszego grzechu”, który w konsekwencji prowadzi do koncepcji „śmierci pierworodnej”. Owa ,promogenita mors" nie wydaje się jednak mieć wiele wspólnego z ,grzechem pierworodnym” (łacińskie określenie ,peccatum oryginale" też na to nie wskazuje), gdyż nie znajdujemy tu odwołań do pierwszych rozdziałów Księgi Rodzaju.

Również ta interpretacja Grzegorza Wielkiego trafiła na karty Glossa Ordinaria, gdzie literalnie zacytowano jej fragmenty ${ }^{16}$.

15 "Brachiorum vero nomine non incongrue opera designantur, quia corporale opus brachiis agitur. Quid autem mors nisi peccatum est, quod ab interiore vita animam occidit? unde scriptum est: Beatus et sanctus qui habet partem in resurrectione prima (Apoc. XX, 6), quia ille post in carne feliciter resurget, qui, in hac vita positus, a mentis suae morte resurrexerit. Si igitur peccatum mors, non incongrue primogenita mors superbia valet intelligi, quia scriptum est: Initium omnis peccati superbia (Eccli. X, 15) . Pulchritudinem igitur cutis eius et brachia illius primogenita mors devorat, quia iniqui gloriam vel operationem superbia supplantat. Potuit enim etiam in hac vita sine culpa gloriosus existere, si superbus minime fuisset" (Gregorius I, Moralia 14, 16, 19 ad Job 18,13, tł. ŹM 44, s. 169).

16 Anselmus Laudunensis, Radulfus Laudunensis et schola, Glossa ordinaria, In Iob, ad loc: "Primogenita mors - superbia quae est initium omnis peccati. Pulchritudinem ergo cutis eius et brachia illius primogenita mors devorat: qua iniqui gloriam vel operationem superbia supplantat. Potuit enim et in hac vita gloriosus existere, si superbus minime fuisset". 


\section{3. Śmierć jako diabel („diabolus”)}

Trzecia interpretacja symboliczna śmierci kojarzy ją z Szatanem:

Śmierć to diabeł, jak w Apokalipsie: „Mam klucze śmierci i piekła” (Ap 1,18), to jest, władzę nad diabłem i jego członkami („Mors, diabolus, ut in Apocalypsi: Habeo claves mortis et inferni, id est, potestatem super diabolum et membra ejus") ${ }^{17}$.

Zgodnie z kontekstem biblijnym zacytowane słowa Apokalipsy są wypowiadane przez zmartwychwstałego Chrystusa, który w widzeniu powierza autorowi księgi listy do siedmiu kościołów. Pseudo-Garnier rozwija symbolikę śmierci i piekła, odnosząc je do diabła i jego członków. W tle jawi się idea teologiczna ,ciała Szatana” złożonego z tych, którzy do niego należą, jako swoista antyteza Mistycznego Ciała Chrystusa złożonego z chrześcijan w myśl metafory ciała z Pierwszego Listu do Koryntian (10-12). Chrystus posiada władzę nad szatanem i jego ciałem, co zostało wyrażone za pomocą symboliki kluczy, wywodzącej się zarówno z prostego skojarzenia (klucze dają możliwość otwierania i zamykania tylko temu, kto je posiada), jak również ewangelijnego motywu powierzenia kluczy, czyli władzy, Piotrowi (Mt 16,19).

Szukając inspiracji dla symboliki śmierć - szatan Pseudo-Garniera z Langres, podobieństwa leksykalne wiodą nas ku Glossa Ordinaria, gdzie w ramach komentarza do Ap 1,18 czytamy słowa włożone w usta Chrystusa:

Przeto nie będę was doświadczał ponad to, co znieść możecie, gdyż mam władzę nad diabłem i jego członkami, nad śmiercią i otchłanią. Diabeł jest śmiercią, gdyż jest przyczyną grzechu, to jest śmierci; otchłanią są jego słudzy, w których ma swoje miejsce ${ }^{18}$.

Jak wiadomo, Glossa Ordinaria jest dziełem kompilacyjnym, stąd też możemy postawić dalsze pytanie, skąd przedstawiona interpretacja tam

17 Pseudo-Garnerius Lingonensis, Allegoriae totius Sacrae Scripturae, Mors, PL 112, 1002A.

18 Anselmus Laudunensis, Radulfus Laudunensis et schola, Glossa ordinaria, Apocalypsis Beati Ioannis, ad loc.: „Ideo non patiar vos tentari supra quam potestis ferre, quia habeo potestatem super diabolum et super membra eius. Mortis et inferni. Diabolus est mors, quia causa est peccati, id est mortis; ministri eius sunt infernus, in quibus habet locum”. 
trafiła. Sądzimy, że trop wiedzie dalej do dzieł samego Anzelma z Laon $(† 1117)$, który w swoim Komentarzu do Apokalipsy napisanym przed Glossa Ordinaria, wyjaśnia:

I mam klucze śmierci i otchłani, to jest diabła i jego członków. On sam jest nazywany śmiercią, gdyż jest przyczyną wszelkiej śmierci; otchłanią są jego słudzy, gdyż to jest miejsce, w którym sam zamieszkuje. Jednak ani diabeł, ani jego słudzy nie mogą szkodzić, jak tylko ta tyle, na ile im Bóg pozwoli ${ }^{19}$.

Nawet ta interpretacja jednak nie wydaje się oryginalnym pomysłem Anzelma z Laon, gdyż nie jest wykluczone, że inspiracją do niej był ceniony w średniowieczu komentarz przypisywany Hajmonowi z Halberstadt będący w rzeczywistości dziełem opata Hajmona z Auxerre (†865):

Przeto Syn Boży ma klucze śmierci i otchłani, gdyż w swoim tajemnym rozstrzygnięciu daje władzę diabłu lub jego członkom, aby srodze prześladowali świętych, z kolei zaś kiedy chce, sprawia, że łagodnieje wszelkie prześladowanie $\mathrm{z}$ ich strony ${ }^{20}$.

Mimo podobieństw leksykalnych idea zawarta w komentarzu Hajmona z Auxerre kontrastuje z interpretacjami Glossa Ordinaria i PseudoGarniera z Langres, gdyż ci ostatni „władzę” (,,potestas”) sytuują w rękach Chrystusa, podczas gdy opat z Auxerre pisze o udzieleniu ,władzy” (,,potestas") szatanowi.

19 Anselmus Laudunensis, Enarrationes in Apocalypsin, 1, ad Ap 1,18: „Et habeo claves mortis et inferni, id est diaboli et membrorum eius. (1506D) Ipse dicitur mors, quia est causa totius mortis: ministri eius infernus, quia locus est in quo ipse habitat. Sed neque diabolus, neque ministri eius possunt nocere, nisi quantum eis a Deo permittitur".

20 Haymo Antissiodorensis, Explicatio in Apocalypsin, 1 ad Ap 1,18: "Habet itaque Filius Dei claves mortis et inferni, quia sua occulta reseratione dat potestatem diabolo, vel eius membris, ut saeviant in persecutionem sanctorum, et iterum cum vult, facit omnem conquiescere eorum tentationem". Na temat atrybucji, zob. C. Spicq, Esquisse d'une histoire de l'exégèse latine au moyen age, Paris 1944, s. 51; P. Glorieux, Pour revaloriser Migne, Mélanges de science religieuse. Cahier supplémentaire, Lille 1952, s. 57; Stegmüller, Repertorium Biblicum Medii Aevi, t. 3, s. 3072, 3122 („Summa probabilitate est Haimonis de Auxerre"); I. Machielsen, Clavis patristica Pseudoepigraphorum Medii Aevi, Turnhaut 1994, s. 2293; B. Gansweidt, Lexicon des Mittel Alters, t. 4, München 2002, s. 1864. 


\section{4. Śmierć jako nienawiść do braci („fraternum odium”)}

Według czwartej interpretacji symbolicznej, śmierć oznacza nienawiść pomiędzy braćmi:

Śmierć to nienawiść do braci, jak w psalmie: „I strach śmierci przypadł na mnie" [Ps 55,5], to jest, lękałem się, aby nienawiść do braci mnie nie przemogła [„Mors, fraternum ${ }^{21}$ odium, ut in psalmo ${ }^{22}$ : Et formido mortis cecidit super me, id est, timui, ne fraternum ${ }^{23}$ odium praevaleret mihi" $]^{24}$.

Kontekst wersetu stanowiącego fragment psalmu o charakterze lamentacyjnym wskazuje na podmiot liryczny w sytuacji opresji, zagrożenia, prześladowania. Jego sytuacja jest na tyle beznadziejna, że oczom jego serca jawi się perspektywa możliwej śmierci, wywołująca lęk. Średniowieczny komentator, odnosząc ten werset do swojej sytuacji egzystencjalnej, jako motyw lęku wskazuje na możliwe do pojawienia się w jego sercu uczucie nienawiści do braci. To uczucie jawi się jako napierająca siła, której on musi się przeciwstawić (,ne fraternum odium praevaleret mihi”).

Szukając w literaturze patrystycznej i średniowiecznej możliwych inspiracji dla powyższej interpretacji, natrafiliśmy na Komentarz do Psalmów ${ }^{25}$ przypisywany Bedzie Czcigodnemu, będący prawdopodobnie autorstwa alzackiego kanonika augustiańskiego Manegolda z Lautenbach $(† 1103)$. Pisze on:

„Strach śmierci przypadł na mnie”, to jest lęk nie tyle przed śmiercią fizyczną, ile duchową. Nie lękał się bowiem śmierci fizycznej, przeciwko której

\footnotetext{
21 fratenum] supernum $m$

22 psalmo] Psalmis $m$

23 fratenum] supernum $m$

24 Pseudo-Garnerius Lingonensis, Allegoriae totius Sacrae Scripturae, Mors; PL 112, 1002A.

25 Manegoldus Lautenbacensis = Pseudo Beda Venerabilis, De libro Psalmorum, PL 93, 477-1097. Negacja autorstwa Bedy, bez podania atrybucji, zob. Machielsen, Clavis patristica Pseudoepigraphorum Medii Aevi, s. 2058c; Stegmüller, Repertorium Biblicum Medii Aevi, t. 2, s. 1665; Przypisanie Manegoldowi z Lauterbach: G. Morin, Le PseudoBède sur les Psaumes et l'Opus super Psalterium de Maître Manegold de Lautenbach, „Revue Bénedictine” 28 (1911) s. 331-340; H. Weisweiler, Die handschriftlichen Vorlagen zum Erstdruck von Beda, In Psalmorum Librum exegesis, „Biblica” 18 (1937) s. 197-204; P. Glorieux, Pour revaloriser Migne, Mélanges de science religieuse. Cahier supplémentaire, Lille 1952, s. 52.
} 
Bóg umocnił go słowami: „Nie bójcie się tych, którzy zabijają ciało, lecz duszy zabić nie mogą" (Mt 10,28). Lękał się raczej śmierci duchowej, która jest straszniejsza, to jest, lękał się nienawiści, bowiem tak jak miłość jest życiem, tak też nienawiść jest śmiercią duszy ${ }^{26}$.

Zauważmy, że o ile symbolika zaproponowana przez Manegolda z Lautenbach odnosi się do nienawiści szeroko pojętej (w domyśle nienawiść dotyczy wrogów, agresorów), to Pseudo-Garnier z Langres zawęża ją do kręgu braci („fraternum odium”), a więc kogoś bliskiego. Ponadto wydźwięk symboliki sugeruje jako adresata człowieka prowadzącego pogłębione życie duchowe. Na tej podstawie możemy sądzić, że Pseudo-Garnier z Langres dokonał swoistej kontekstualizacji symboliki, odnosząc ją do środowiska mniszego, w którym powstało dzieło. Niewykluczone, że w społeczności zamkniętej, którą obowiązywała stabilitas loci, a ponadto funkcjonowały relacje o charakterze feudalnym, wzajemne animozje, rywalizacja, zazdrość, trudność z zaakceptowaniem inności drugiego mogły rodzić nie tylko frustracje, ale i uczucie nienawiści do poszczególnych braci. Równocześnie konieczność trwania we wspólnocie i obcowania w różnych sytuacjach życiowych nie tylko uniemożliwiała odcięcie się i zaniechanie kontaktu z danym współbratem, ale mogła nawet potęgować napór tego negatywnego uczucia, co może kryć się za słowami „aby nienawiść [...] nie przemogła” (,ne [...] odium praevaleret"). Sytuacja taka staje się wyzwaniem dla pracy ascetycznej, aby miłość (życie) zwyciężyła nad nienawiścią (śmiercią), której osobiste świadectwo daje autor glosariusza.

\section{5. Śmierć jako grzech (,peccatum”)}

Kolejną interpretacją śmierci jest postrzeganie jej jako symbolu grzechu:

Śmierć to grzech, jak w psalmie: „Abym nigdy nie zasnął w śmierci” [Ps 13,4], to jest, abym nigdy nie znalazł spoczynku w grzechu (,Mors, peccatum, ut

26 Manegoldus Lautenbacensis, De libro Psalmorum, ad loc.: „Cecidit super me formido mortis, id est, timor mortis non exterioris, sed interioris. Non enim timebat mortem exteriorem, contra quam munierat eum Dominus dicens: Nolite timere eos qui corpus occidunt, animam autem non possunt occidere; timeba(n)t mortem interiorem, quae gravior est, id est, odium timeba(n)t, quia sicut dilectio est vita, ita odium est mors animae". 
in psalmo ${ }^{27}$ : Ne unquam obdormiam in morte, id est, ne unquam requiescam in peccato" $)^{28}$.

Wprawdzie określenie „grzech śmiertelny” (,peccatum mortale”) na dobre zagościło w teologii moralnej dopiero za sprawą Tomasza z Akwinu, niemniej jednak skojarzenie grzechu ze śmiercią jest już obecne na kartach Nowego Testamentu. Autor Pierwszego Listu św. Jana rozróżnia kategorie grzechu, wśród których wymienia ,taki grzech, który sprowadza śmierć” (,hamartia pros thanaton” - 1J 5,16). Specyfiką interpretacji, jaką znajdujemy u Pseudo-Garniera z Langres, jest paradoksalne poniekąd połączenie (w oparciu o fragment psalmu mówiący o spoczynku w śmierci) idei odpocznienia z grzechem („ne unquam requiescam in peccato”). Opiera się ono na skojarzeniu snu ze śmiercią, które dwukrotnie pojawia się w glosariuszu: najpierw w kontekście hasła „zaśnięcie”29, następnie zaś w kontekście hasła „sen" ${ }^{30}$.

Również w tym przypadku sądzimy, że inspiracją dla Pseudo-Garniera z Langres był Komentarz do Psalmów przypisywany Bedzie Czcigodnemu:

„Oświeć” - powiadam - ,abym nigdy nie zasnął w śmierci”, to jest, nie spoczął w sprzeciwie wobec Twoich przykazań, idąc ku śmierci, to jest ku wszelkiemu grzechowi zbrodniczemu, który jest śmiercią ${ }^{31}$.

Tylko w tym komentarzu do Ps 13,4 (poza, oczywiście, samym skojarzeniem grzechu ze śmiercią) znajdujemy leksykalne podobieństwo, dzięki użyciu czasownika ,acquiescam” (spoczywam) wywodzącego się z tego samego rdzenia oraz mającego znaczenie synonimiczne do „requiescam” ('znajduję spoczynek') użytego przez Pseudo-Garniera z Langres.

Samo jednak odniesienie metaforyczne grzechu do śmierci symbolizowanej przez zaśnięcie w oparciu o omawiany powyżej werset psalmu wy-

\footnotetext{
27 psalmo] Psalmis $m$

28 Pseudo-Garnerius Lingonensis, Allegoriae totius Sacrae Scripturae, Mors, PL 112, 1002A-B.

29 Pseudo-Garnerius Lingonensis, Allegoriae totius Sacrae Scripturae, Dormitio; PL 112,913A.

30 Pseudo-Garnerius Lingonensis, Allegoriae totius Sacrae Scripturae, Somnus; PL 112,1059B.

31 Manegoldus Lautenbacensis, De libro Psalmorum, ad loc.: „Illumina, dico, ne unquam obdormiam in morte, id est, contra praecepta tua mihi acquiescam eundo in mortem, id est, in aliquod criminale peccatum, quod sit mors".
} 
daje się szeroko rozpowszechnione w interpretacji średniowiecznej, zapewne w oparciu o krótki komentarz Augustyna zawarty w Objaśnieniach do Psalmów: „«Oświeć moje oczy, abym nigdy nie zasnął w śmierci». Należy rozumieć: oczy serca; ażeby nie zamknęły się skutkiem przynoszącego uciechę zaćmienia grzechu"32. Echa słów Augustyna znajdujemy w dziele Remigiusza z Auxerre ( $\dagger$ ok. 908) noszącym ten sam tytuł co komentarz biskupa Hippony, który jednak dodaje od siebie moralizatorską wstawkę dotyczącą życia cnotliwego: „Niechże tak czynię, «abym nigdy nie zasnął w śmierci», to jest, nie zasnął w grzechach na przekór owemu światłu, zaprzestając [praktykowania] cnót"33. Powyższy komentarz stał się inspiracją dla Glossa Ordinaria, gdzie poza metaforyką światła rozbudowaną o motyw wiary myśl augustiańska została rozwinięta dzięki przytoczeniu cytatu z 1J 5,16: „«Zasnę», gdy pogrzebawszy światło wiary, przez cielesną rozkosz [oczy] zostaną zamknięte. «W śmierci», to jest w grzechu przeciwko Duchowi Świętemu, o którym [pisze] Jan: «Jest grzech ku śmierci, nie za niego mówię, aby się modlić»»"34. Powyższy cytat z Listu św. Jana będzie towarzyszył interpretacji Ps 13,4 w późniejszych komentarzach, spośród których wystarczy zacytować chociażby słynne dzieło Piotra Lombarda:

„Abym nigdy nie zasnął w śmierci”, to jest, nie został omotany przez jakikolwiek grzech zbrodniczy. Albo: „W śmierci”, to jest w grzechu przeciw Duchowi Świętemu, o którym mówi Jan: „Jest grzech ku śmierci, nie za niego mówię, aby się modlić”. Mówię: „abym nie zasnął” w odniesieniu do mnie, ale też w odniesieniu do innych ${ }^{35}$.

32 „Illumina oculos meos, ne unquam obdormiam in morte. Oculos cordis oportet intellegi, ne delectabili defectu peccati claudantur" (Augustinus Hipponensis, Enarrationes in Psalmos, ad Ps 12,4, tł. J. Sulowski, Augustyn, Objaśnienia Psalmów, PSP 37, Warszawa 1986, s 129-130). Ten werset psalmu J. Sulowski tłumaczy „Oświeć oczy moje, bym nie zasnął na śmierć".

33 Remigius Antissiodorensis, Enarrationes in Psalmos, ad loc.: „Hoc autem ideo faciam (facias corr.), ne unquam obdormiam in morte, id est, contra illam lucem dormiam in peccatis, cessando a virtutibus".

34 Anselmus Laudunensis, Radulfus Laudunensis et schola, Glossa ordinaria, In Psalmos, ad loc.: "Obdormiam. Quando fidei lumine sepulto, carnali delectatione clauduntur. In morte. Id est, in peccato quod fit in Spiritum sanctum de quo Ioannes: Est peccatum ad mortem, non pro eo dico ut quis oret".

35 Petrus Lombardus, Commentaria in Psalmos, ad loc.: „Vel, ne unquam obdormiam in morte, id est ne obvolvar quolibet criminali peccato. Vel, in morte, id est in peccato quod fit in Spiritum sanctum, de quo dicit Ioannes: Est peccatum ad mortem, non pro eo dico ut quis oret. Dico non obdormiam per me, nec etiam per alium”. 


\title{
6. Śmierć jako kara wieczna (,poena aeterna”)
}

\author{
Ostatnie w końcu skojarzenie symboliczne śmierci u Pseudo-Garniera \\ z Langres dotyczy kary wiecznej
}

Śmierć to kara wieczna, jak u Pawła: „Którzy takie rzeczy czynią, godni są śmierci” (Rz 1,32), to jest, godni są kary wiecznej (,Mors, poena aeterna, ut in Paulo: Qui talia agunt, digni sunt morte, id est, digni sunt poena aeterna") ${ }^{36}$.

Również w tym wypadku wydaje się, że bezpośrednim źródłem dla Pseudo-Garniera z Langres była Glossa Ordinaria. Jedynie tutaj pojawia się w kontekście komentarza do Rz 1,32 użycie zarówno rzeczownika ,poena” ('kara'), jak i przymiotnika „aeterna” ('wieczna'): „«Godni są śmierci». Niech nie sądzi się, że tych tylko dosięgną kary, którym należy się, dodaje „ostateczna”, śmierć wieczna. «Którzy czyniącym zezwalają», itd. Zezwalać to znaczy milczeć, gdy mógłbyś upomnieć lub błąd naprawić" ${ }^{37}$. Końcowe wersety pierwszego rozdziału Listu do Rzymian zostały w Glossa Ordinaria skomentowane w oparciu o dzieło Augustyna Przeciw Julianowi. Autor nie cytuje jednak explicite biskupa Hippony, lecz wtrąca krótkie uwagi, które czasami utrudniają zrozumienie tekstu. Tak też jest w tym przypadku, gdzie czasownik ,addit” ('dodaje') wskazuje na dodany przymiotnik ,ultima” ('ostateczna'), przy pomocy którego Augustyn zinterpretował słowa św. Pawła. Apostoł w swoim liście mówi o śmierci, Augustyn zaś dodaje ,śmierci ostatecznej”: ,Jakże aż takie i tak wielkie zło w niej (pożądliwości) zawarte, nie miałoby więzić w śmierci i ciągnąć ku ostatecznej śmierci, gdyby jej pęta nie były rozwiązywane dzięki odpuszczeniu grzechów, jakie dokonuje się przy Chrzcie?”38. Augustyn nie używa więc określenia „,mors aeterna”, lecz

36 Pseudo-Garnerius Lingonensis, Allegoriae totius Sacrae Scripturae, Mors, PL 112, 1002B.

37 Anselmus Laudunensis, Radulfus Laudunensis et schola, Glossa ordinaria, In Psalmos, ad loc.: „Digni sunt morte. Ne putentur his tantum poenis affligi quibus delectantur, addit ultimam, mortem aeternam. Qui consentiunt facientibus, etc. Consentire est tacere, cum possis arguere; vel errorem fovere".

38 „Tale porro ac tam magnum malum, tantum quia inest, quomodo non teneret in morte et pertraheret in ultimam mortem, nisi et eius vinculum in illa quae fit in Baptismo remissione peccatorum omnium solveretur?" (Augustinus Hipponensis, Contra Julianum, 6, 15, 48, tł. W. Eborowicz, Augustyn, Przeciw Julianowi, PSP 19/2, Warszawa 1977, s. 197). W tekście artykułu podaję własne tłumaczenie. Przekład W. Eborowicza dokonuje pewnych interpretacji: „Czyż takie i tak wielkie zło na skutek samej swej obecności nie poddawałoby nas we władanie śmierci fizycznej, a nawet wiecznej? Tak by się stało, 
„mors ultima”, Glossa Ordinaria natomiast czyni z tych wyrażeń frazy synonimiczne (,addit ultimam, mortem aeternam"). Autor badanego przez nas glosariusza dokonuje kolejnej interpretacji, przenosząc przymiotnik ,aeterna” ('wieczna') z „mors” ('śmierć') do ,poena” ('kara').

Zresztą interpretacja Rz 1,32 w kontekście eschatologicznym staje się powszechna $\mathrm{w}$ komentarzach średniowiecznych. Znajdujemy ją w Komentarzu do Apokalipsy Ruperta z Deutz, według którego św. Paweł pisze o „przyszłej karze grzeszników” („futura peccatorum poena”) ${ }^{39}$. Dla Piotra Abelarda „śmierć wieczna” stanowi „należną pomstę za poszczególne grzechy” (,debitam uindictam de singulis peccatis") ${ }^{40}$, inni zaś po prostu dodają do Pawłowego zwrotu ,godni są śmierci” (,digni sunt morte”) przymiotnik „wiecznej” (,aeterna”) ${ }^{41}$. Zwieńczeniem tejże tradycji interpretacyjnej będzie stwierdzenie Tomasza z Akwinu zawarte w Sumie Teologicznej: „Należy stwierdzić, że wszyscy, którzy grzeszą śmiertelnie, «godni są śmierci» (Rz 1,32) wiecznej, dotyczącej przyszłej odpłaty, która dokonuje się zgodnie z prawdą Bożego sądu"42.

\section{Konkluzja}

Pseudo-Garnier z Langres zawarł w swoim glosariuszu symboli biblijnych sześć alegorycznych znaczeń śmierci. Kojarzy się ona z umartwieniem, pychą, diabłem, nienawiścią do braci, grzechem oraz wieczną karą przeznaczoną dla grzeszników. Wszystkie interpretacje alegoryczne mają wydźwięk moralny i zdecydowana większość (z wyjątkiem umartwienia) ujmuje śmierć z negatywnej perspektywy.

W toku badań udało się dotrzeć do wszystkich źródeł stanowiących bezpośrednie inspiracje dla Pseudo-Garniera z Langres, są to mianowicie Moralia Grzegorza Wielkiego, Glossa Ordinaria oraz Komentarz do Psalmów Manegolda z Lautenbach przypisywany Bedzie Czcigodnemu.

gdyby chrzest udzielający odpuszczenia wszystkich grzechów nie uwolnił nas z więzów owego zła".

39 Rupertus Tuitiensis, Commentaria in Apocalypsim 9, 16.

40 Petrus Abaelardus, Expositio in Epistolam Pauli ad Romanos, ad loc.

41 Bruno Carthusianorum, Expositio in epistolas Pauli, ad loc.; Petrus Lombardus, Collectanea in epistolas Pauli, ad loc.

42 „Dicendum quod omnes peccantes mortaliter digni sunt morte aeterna quantum ad futuram retributionem, quae est secundum veritatem divini iudicii” (Thomas de Aquino, Summa Theologiae, II-II, 108, 3). 
Jednak pośrednio można dopatrzeć się inspiracji sięgających nawet św. Augustyna.

Autor glosariusza stara się pozostać wierny źródłom, z których korzysta. Ma świadomość, że jego praca stanowi posługę mającą na celu uporządkowanie i sklasyfikowanie spuścizny interpretacji alegorycznej. Jego dzieło nie ma charakteru twórczego, lecz stara się przedstawić te skojarzenia symboliczne, które stanowią główny nurt chrześcijańskiej alegorystyki biblijnej. Tym niemniej jednak drobne szczegóły leksykalne i interpretacyjne wskazują na indywidualne podejście do tekstu biblijnego oraz osadzenie jego rozumienia w egzystencjalnym kontekście życia autora - mnicha XIIwiecznego opactwa cysterskiego żyjącego według Reguły św. Benedykta.

\section{Death as Carrier of Symbolical Meanings - in Search of Patristic Inspirations of Pseudo-Garnier of Langres}

(summary)

Pseudo-Garnier of Langres included six allegorical meanings of death in his glossary of biblical symbols. Death is associated with mortification, pride, the devil, hatred among brothers, sin, and eternal punishment for sinners. All allegorical interpretations are moral and the vast majority (except mortification) consider death from a negative perspective. In the course of the research, it was possible to find all the sources that were direct inspirations for Pseudo-Garnier of Langres, namely: The Moralia of Gregory the Great, Glossa Ordinaria and the Commentary on Psalms of Manegold of Lautenbach, attributed to Bede the Venerable. However, indirectly we can find inspiration reaching back to St. Augustine. The glossary author tries to remain faithful to the sources he uses. He is aware that his work is a ministry aimed at organizing and classifying the legacy of allegorical interpretation. His work is not creative, but tries to present the symbolic associations that constitute the mainstream of biblical Christian allegorization.

Keywords: death; symbol; Bible; Garnier of Langres; allegorical interpretation

\section{Śmierć jako nośnik znaczeń symbolicznych - w poszukiwaniu patrystycznych inspiracji Pseudo-Garniera z Langres}

(streszczenie)

Pseudo-Garnier z Langres zawarł w swoim glosariuszu symboli biblijnych sześć alegorycznych znaczeń śmierci. Kojarzy się ona z umartwieniem, pychą, diabłem, nienawiścią do braci, grzechem oraz wieczną karą przeznaczoną dla grzeszników. Wszystkie interpretacje alegoryczne mają wydźwięk moralny i zdecydowana większość (z wyjątkiem umartwienia) ujmuje śmierć z negatywnej perspektywy. W toku badań udało się dotrzeć do 
wszystkich źródeł stanowiących bezpośrednie inspiracje dla Pseudo-Garniera z Langres. Sa to mianowicie Moralia Grzegorza Wielkiego, Glossa Ordinaria oraz Komentarz do Psalmów Manegolda z Lautenbach przypisywany Bedzie Czcigodnemu. Jednak pośrednio można dopatrzeć się inspiracji sięgających św. Augustyna. Autor glosariusza stara się pozostać wierny źródłom, z których korzysta. Ma świadomość, że jego praca stanowi posługę mającą na celu uporządkowanie i sklasyfikowanie spuścizny interpretacji alegorycznej. Jego dzieło nie ma charakteru twórczego, lecz stara się przedstawić te skojarzenia symboliczne, które stanowią główny nurt chrześcijańskiej alegorystyki biblijnej.

Słowa kluczowe: śmierć; symbol; Biblia; Garnier z Langres; interpretacja alegoryczna

\section{Bibliografia}

\section{Źródla}

Anselmus Laudunensis, Enarrationes in Apocalypsin, PL 169, 1499-1586.

Anselmus Laudunensis, Radulfus Laudunensis et schola, Glossa ordinaria, PL 113-114. Augustinus Hipponensis, Contra Julianum, PL 44, 641-874, tł. W. Eborowicz, Augustyn, Przeciw Julianowi, PSP 19/1-2, Warszawa 1977.

Augustinus Hipponensis, Enarrationes in Psalmos, ed. E. Dekkers - J. Fraipont, CCL 38-40, tł. J. Sulowski, Augustyn, Objaśnienia Psalmów, PSP 37-42, Warszawa 1986. Bruno Carthusianorum, Expositio in epistolas Pauli, PL 153, 11-567.

Garnerius Lingonensis (Pseudo), Allegoriae totius Sacrae Scripturae, PL 112, 8491088, tł. P.G. di Domenico, Rabano Mauro (pseudo), Allegorie sulla Scrittura, Cittá del Vaticano 2002; tł. P. Throop, Anonymous, Allegories in All Holy Scripture, Charlotte, Vermont 2009.

Gregorius I, Moralia in Job, ed. M. Adriaen, CCL 143A-B, tł. T. Fabiszak - A. Strzelecka - R. Wójcik, Grzegorz Wielki, Moralia. Komentarz do Księgi Hioba, tom 1, ks.1-5, Źródła Monastyczne 39, Tyniec 2006; K. Nastał, L. Gładyszewski, A. Wójcik, E. Buszewicz: Grzegorz Wielki, Moralia. Komentarz do Ksiegi Hioba, tom 2, ks.6-10, Źródła Monastyczne 41, Tyniec 2006; S. Naskręt, E. Buszewicz, K. Nastał. L. Gładyszewski: Grzegorz Wielki, Moralia. Komentarz do Księgi Hioba, tom 3, ks.11-16, Źródła Monastyczne 44, Tyniec 2007; E. Buszewicz, A. Wilczyński: Grzegorz Wielki, Moralia. Komentarz do Księgi Hioba, tom 4, ks.17-22, Źródła Monastyczne 63, Tyniec 2013; A. Wilczyński: Grzegorz Wielki, Moralia. Komentarz do Księgi Hioba, tom 5, ks.23-27, Źródła Monastyczne 75, Tyniec 2015; A. Wilczyński: Grzegorz Wielki, Moralia. Komentarz do Księgi Hioba, tom 6, ks.28-32, Źródła Monastyczne 77, Tyniec 2016; A. Wilczyński: Grzegorz Wielki, Moralia. Komentarz do Księgi Hioba, tom 7 ks.33-35, Źródła Monastyczne 78, Tyniec 2016.

Haymo Antissiodorensis, Explicatio in Apocalypsin, PL 70, 1056-1106 = PL 117, 295-358, Manegoldus Lautenbacensis, De libro Psalmorum, PL 93, 477-1097. 
Petrus Abaelardus, Expositio in Epistolam Pauli ad Romanos, PL 178, 783-978.

Petrus Lombardus, Collectanea in epistolas Pauli, PL 191, 1296-192, 520.

Petrus Lombardus, Commentaria in Psalmos, PL 191, 55-1296.

Remigius Antissiodorensis, Enarrationes in Psalmos, PL 131, 133-844.

Rupertus Tuitiensis, Commentaria in Apocalypsin, PL 169, 825-1214.

Thomas de Aquino, Summa Theologiae, t. 1-3, opr. P. Caramello, Torino - Roma 19521956, tł. G. Kurylewicz - Z. Nerczuk - M. Olszewski, Traktat o Bogu. Summa teologii, kwestie 1-26, Kraków 1999.

\section{Opracowania}

Bardski K., Medieval Glossary of Biblical Symbols - Pseudo-Garnier's of Langres „Allegoriae in Universam Sacram Scripturam”, „Wrocławski Przegląd Teologiczny” 27/2 (2019) s. 33-42.

Bardski K., Alegoryczno-symboliczna interpretacja Biblii, Kraków 2016.

Bardski K., Rzecz-symbol jako locus theologicus w ponaddosłownej interpretacji Biblii, „Ethos” 33 (2020) (w druku).

Gansweidt B., Lexicon des Mittel Alters, München 2002.

Glorieux P., Pour revaloriser Migne, Mélanges de science religieuse. Cahier supplémentaire, Lille 1952.

Machielsen I., Clavis patristica Pseudoepigraphorum Medii Aevi, Turnhaut 1994.

Morin G., Le Pseudo-Bède sur les Psaumes et l'Opus super Psalterium de Maître Manegold de Lautenbach, „Revue Bénedictine” 28 (1911) s. 331-340.

Spicq C., Esquisse d'une histoire de l'exégèse latine au moyen age, Paris 1944.

Stegmüller F., Repertorium Biblicum Medii Aevi, Madrid 1950.

Weisweiler H., Die handschriftlichen Vorlagen zum Erstdruck von Beda, In Psalmorum Librum exegesis, „Biblica” 18 (1937) s. 197-204.

Wilmart A., Les Allégories sur l'Écriture attribuées à Raban Maur, „Revue Bénedictine" 32 (1920) s. 47-56. 